\title{
Teknologi Disk Mill dan sistem Dry Home pada peternak itik petelur di Cambajawa Desa Baruga Kecamatan Bantimurung Kabupaten Maros
}

\author{
Mukhlisin $^{1}$, Irvawansyah ${ }^{2}$ \\ ${ }^{1,2}$ Teknik Listrik, Politeknik Bosowa, Makassar
}

\begin{abstract}
The Community Partnership Program (PKM) partners are laying eggs duck farmers in Cambajawa, Baruga Village, Bantimurung, Maros. The problems are: (1) lack of knowledge in application of animal feed processing technology; (2) lack of skills in application of animal feed processing technology; and (3) animal feed production still relies on the weather. The external target is a grinding machine (Disk Mill) for the manufacture of animal feed and a drying system (Dry Home). The methods used are: speechs, demonstrations, discussions, questions and answers, and assistance. The results achieved were (1) partners have knowledge in application of animal feed processing technology, (2) partners have skills in application animal feed processing technology; and (3) partners can produce animal feed without relying on the weather.
\end{abstract}

Keywords: duck farmers, disk mill, dryhome

\section{PENDAHULUAN}

Program Kemitraan Masyarakat (PKM) yang telah dilaksanakan bermitra dengan UKM Peternak Itik Petelur, yang beralamat di Cambajawa, Desa Baruga Kec. Bantimurung. Kab. Maros dengan pemilik usaha atas nama Amir.

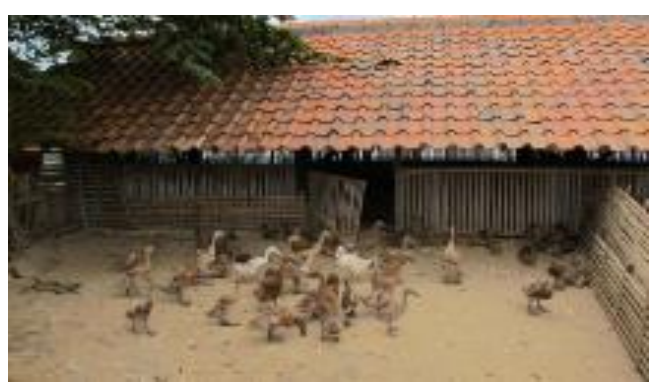

Gambar 1. UKM Mitra PKM

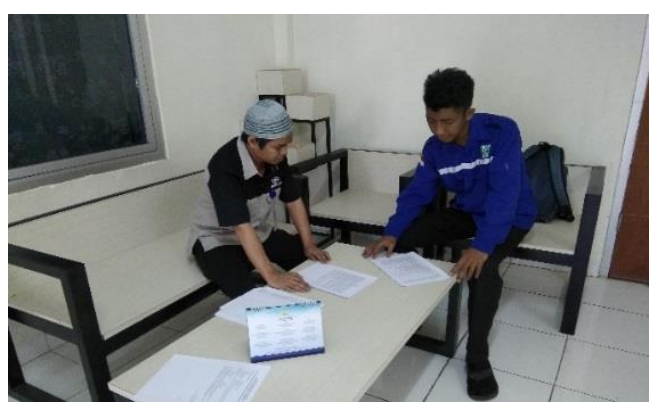

Gambar 2. Penandatangan MoU dengan mitra PKM
Kondisi UKM mitra sebagai berikut:

1. Permintaan telur itik sebagai bahan konsumsi makanan cukup besar.

2. Pemberian pakan merupakan biaya operasional yang paling besar.

3. Bahan baku yang digunakan untuk pembuatan pakan adalah limbah kepala udang.

4. Alat yang digunakan untuk memproduksi pakan ternak masih bersifat konvensional.

5. Selama ini proses pembuatan pakan ternak masih mengandalkan cuaca atau cahaya sinar matahari.

6. Mitra belum menerapkan teknologi dalam pembuatan pakan ternak.

7. Mitra belum memiliki pengetahuan dan keterampilan dalam memanfaatkan teknologi untuk memproduksi pakan ternak.

Ternak itik merupakan salah satu komoditas unggul yang mempunyai peran cukup penting sebagai penghasil telur dan daging untuk mendukung ketersediaan protein hewani yang murah, dan mudah didapat. Di Indonesia, itik umumnya di usahakan sebagai penghasil telur namun ada yang diusahakan sebagai penghasil daging. Peternakan itik didominasikan oleh peternak dengan sistim pemeliharaan yang masih 
tradisional di mana itik di gembalakan di sawah atau ditempat-tempat yang banyak airnya, namun dengan cepat mengarah pada pemeliharaan intensif yang sepenuhnya terkurang (Dramendra, Gunawan, \& Lubis, 2015).

Beberapa cara yang dapat dilakukan untuk membudidayakan itik antara lain dengan metode tradisional dan metode intensif. Metode tradisional adalah metode dengan cara menggembalakan itik di area persawahan. Metode ini tidak dapat diterapkan lagi karena dapat merusak tanaman padi di area persawahan sehingga petani dapat mengalami gagal panen. Metode intensif adalah metode beternak dengan menggunakan kandang dan pengaturan (penjadwalan pemberian) pakan. Sebab pakan memiliki peranan yang sangat signifikan dalam produktivitas itik untuk bertelur (L. Hardi, 2010 ).

Pemeliharaan dengan sistim intensif, pakan sangat tergantung pada peternaknya. Agar itik dapat berproduksi lebih baik maka peternak menyediakan seluruh kebutuhan pakan baik jumlah maupun mutunya sehingga mencukupi kebutuhan gizi itik. Jika peternak dapat menekan biaya/harga pakan, berarti dapat meningkatkan efisiensi biaya produksi, dan pada gilirannya dapat meningkatkan pendapatan (Maharso, 2012).

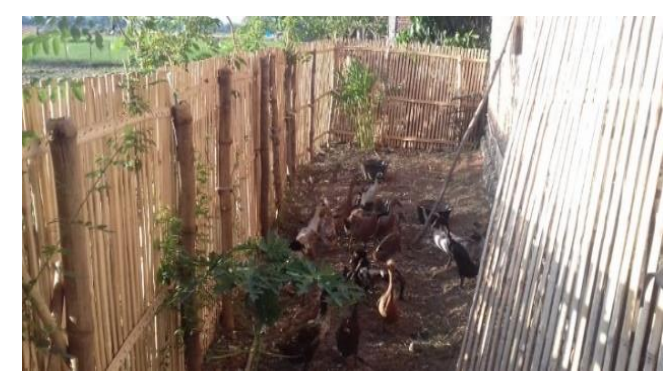

Gambar 3. Peternakan itik sistem modern

Peternakan itik di Indonesia umumnya bertujuan untuk memproduksi telur. Peternakan itik petelur menjadi andalan bagi sebagian besar pelaku usaha peternakan itik di berbagai daerah Indonesia. Tujuan utama para peternak itik masih tetap berorientasi pada produksi telur sebagai penghasil uang. Adapun telur yang dikonsumsi oleh masya- rakat Indonesia umumnya berasal dari unggas yang diternakkan (Kusumayana \& Nafisah, 2017).

Beberapa permasalahan yang dihadapi oleh mitra yaitu mitra kurang memiliki pengetahuan dan keterampilan dalam memproduksi pakan ternak, serta proses produksi pakan ternak masih mengandalkan cuaca atau sinar matahari.

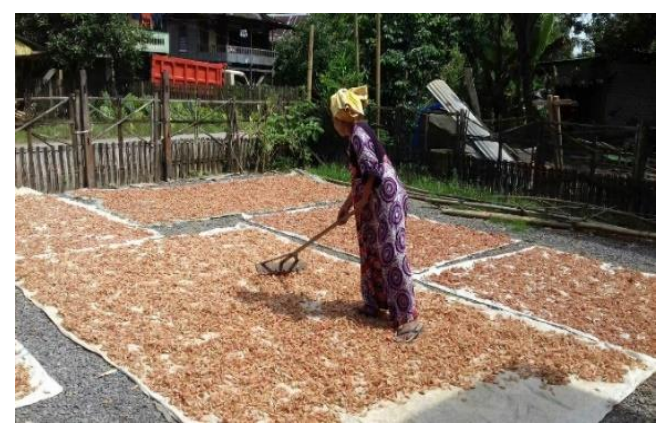

Gambar 4. Pengeringan bahan pakan dengan mengandalkan sinar cuaca/ matahari

\section{METODE PELAKSANAAN}

a. Agar mitra memiliki pengetahuan dalam memanfaatkan teknologi pengolahan pakan ternak maka metode yang digunakan adalah ceramah, demonstrasi, diskusi, dan tanya jawab.

b. Agar mitra memiliki keterampilan dalam memanfaatkan teknologi pengolahan pakan ternak maka metode yang digunakan adalah demonstrasi dan tanya jawab.

c. Agar mitra dapat memproduksi pakan ternak tanpa mengandalkan cahaya sinar matahari maka metode yang digunakan adalah demonstrasi, dan tanya jawab terhadap penggunaan mesin penghalus (Disk Mill) dan alat pengering (Dry Home).

\section{HASIL DAN PEMBAHASAN}

\section{A. Memperkenalkan Bahan Pakan Ternak}

Pada tahapan ini, tim pengabdi memperkenalkan kepada mitra bahan-bahan yang digunakan dalam pembuatan pakan ternak. Setelah mitra mengenali dengan baik bahan tersebut, maka dilanjutkan dengan memperkenalkan alat pembuat pakan ternak. 


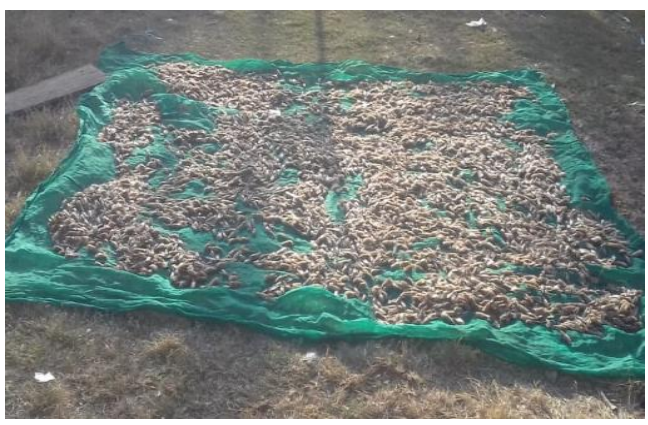

Gambar 5. Kepala udang sebagai bahan pembuatan pakan

\section{B. Memperkenalkan Alat Pengering (Dry Home)}

Pada tahapan ini, tim pengabdi memperkenalkan kepada mitra alat pengering bahan pakan. Setelah mitra mengenali dengan baik alat tersebut, maka dilanjutkan dengan memperkenalkan mesin penghalus bahan pakan.

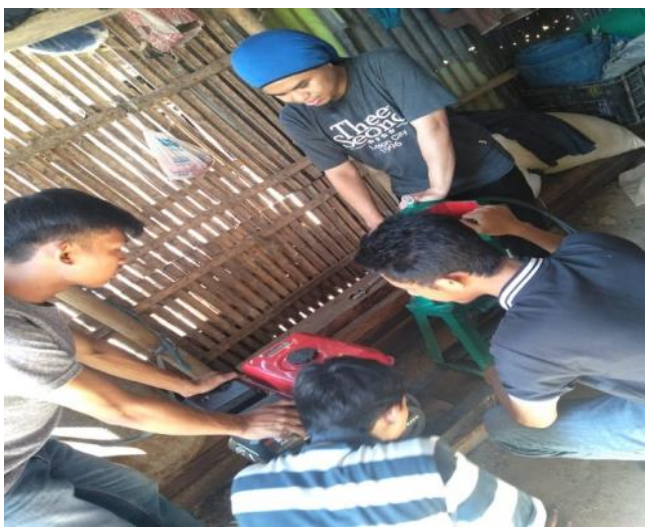

Gambar 6. Memperkenalkan alat pengering (dry home)

\section{Memperkenalkan Mesin Penghalus (Disk Mill)}

Pada tahapan ini, tim pengabdi memperkenalkan kepada mitra mesin penghalus bahan pakan. Setelah mitra mengenali dengan baik mesin tersebut, maka dilanjutkan dengan melatih dan mendampingi mitra memproduksi pakan ternak.

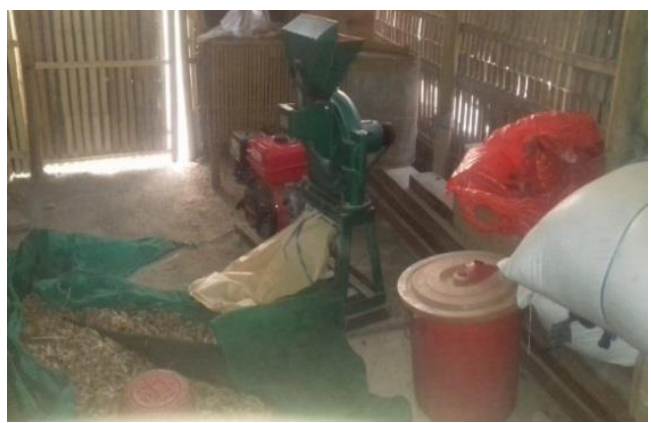

Gambar 7. Memperkenalkan mesin penghalus (disk mill)

\section{Melatih dan Mendampingi Mitra Membuat Pakan Ternak}

Pada tahapan ini, tim pengabdi melatih dan mendampingi mitra memproduksi pakan ternak. pakan ternak yang dihasilkan berupa tepung halus dari bahan dasar limbah kepala udang. Limbah kepala udang didapatkan dari sisa proses industri pengolahan daging udang yang berada diwilayah sekitar lokasi perternakan itik. Setelah proses pelatihan dan pendampingan mitra dalam membuat pakan ternak, maka mitra secara mandiri dapat membuat pakan ternaknya sendiri.

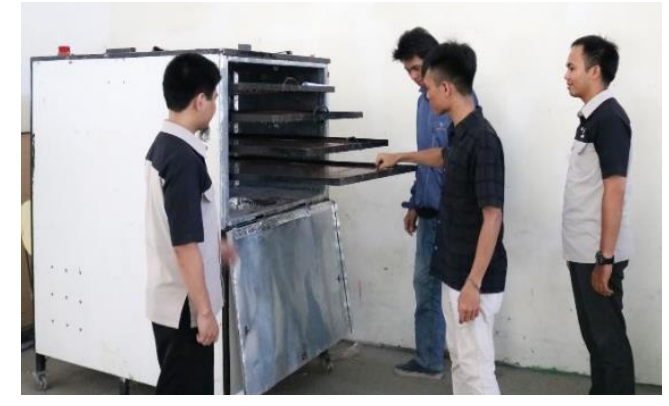

Gambar 8. Melatih dan mendampingi mitra dalam membuat pakan ternak

\section{KESIMPULAN}

Berdasarkan hasil pelaksanaan kemitraan masyarakat yang telah dilakukan maka dapat ditarik kesimpulan sebagai berikut:

1. Mitra memiliki pengetahuan dalam memanfaatkan teknologi pengolahan pakan ternak.

2. Mitra memiliki keterampilan dalam memanfaatkan pengolahan pakan ternak.

3. Mitra tidak lagi mengandalkan cuaca/sinar matahari dalam pembuatan pakan ternak.

\section{UCAPAN TERIMA KASIH}

Ucapan terima kasih disampaikan kepada Direktorat Jendral Pendidikan Tinggi yang telah memberikan hibah. Selanjutnya ucapan terima kasih disampaikan pula kepada Direktur Politeknik Bosowa atas arahan dan pembinaanya selama proses kegiatan Pengabdian Masyarakat berlangsung. Demikian pula ucapan terima kasih disampaikan kepada Ketua Lembaga Penelitian dan Pengabdian Kepada Masyarakat Politeknik 
Bosowa dan Pemerintah Kabupaten Maros Provinsi Sulawesi Selatan, yang telah memberi fasilitas, melakukan monitoring, dan mengevaluasi kegiatan PKM hingga selesai.

\section{DAFTAR PUSTAKA}

Dramendra, Gunawan, I., \& Lubis, A. Analisa Usaha Itik Petelur Di Desa Bangun Purba Timur Jaya Kecamatan Bangun Purba Kabupaten Rokan Hulu. Pengaraian: Fakultas Pertanian Universitas Pengaraian. 2015.
Kusumayana, P. \& Nafisah, S. Strategi Pengembangan Ternak Itik Petelur di Desa Kamayahan Kecamatan Amuntai Utara Kabupaten Hulu Sungai Utara. Jurnal Daun 4 (1) 55-62. 2017

L. Hardi Prasetyo. Panduan Budidaya dan Usaha Ternak Itik. Bogor: Balai Penelitian Tenak. 2010.

Maharso, D., Y. Budidaya Ternak Itik Petelur. Jawa Tengah: Balai Pengkajian Teknologi Pertanian. 2012. 